\begin{tabular}{lc|}
\hline UAD & ADJES (Ahmad Dahlan Journal of English Studies) \\
VOL 8, No. 1, 92-102 \\
$\begin{array}{l}\text { Universitas } \\
\text { Ahmad Dahlan }\end{array}$ \\
https://doi.org/10.26555/adjes.v8i1.17978
\end{tabular}

\title{
The Main Character's Jealousy as Seen in Gillian Flynn's Gone Girl: A Psychological Approach
}

\section{${ }^{1}$ Ganesh Yogi Prabowo, ${ }^{2}$ Astry Fajria}

Email : ${ }^{1}$ yogetzganesh@gmail.com, ${ }^{2}$ astry.fajria@pbi.uad.ac.id 1,2 Universitas Ahmad Dahlan

\section{ARTICLE INFO}

Article history

Received: 14 September 2020

Revised: 18 November 2020

Accepted: 9 April 2021

Keywords

Gillian Flynn

jealousy

psychological approach

\section{ABSTRACT}

Jealousy is part of human's psychological condition. Similarly, Gillian Flynn employed the topic brilliantly in one of her works, Gone Girl. The present study entitled "The Main Character's Jealousy as Seen in Gillian Flynn's Gone Girl" aimed to identify the main character's personality and to describe the causes and impacts of her jealousy. It belongs to library research, with Gillian Flynn's novel as the subject and the aspects of jealousy the object. Since it is about the human psyche, a psychological approach was employed. Further, the theories of jealousy were used to analyze the data and to answer the research questions. The analysis resulted in several findings. First, Amy Dunne, the main character, was found to be a brilliant and cunning person. Her personality, triggered by jealousy, manifests in her actions throughout the story. Second, Amy Dunne is extremely jealous of her husband. She finds out that Nick, her husband, has an affair with another woman, and the feeling leads to several incidents. Amy disappears, fakes various crime that leads the public to hate her husband, and finally returns home. Amy also kills a man to cover her lies; all were done without anyone's suspicion. It is recommended that the next researchers explore the characters of the story more profoundly or employ the work as one alternative material in ELT class.

This is an open access article under the CC-BY-SA license.

\section{Introduction}

Jealousy is an emotional reaction involving many aspects of a relationship. It is not a simple concept, nor a single emotion. Instead, jealousy is a combination of negative emotions (Bringle \& Bunk, as cited in Demirtaz \& Donmez, 2006). When people feel the passion that represents the emotion, it will reflect in the behavior, such as interrogating, monitoring the partner's activities, and getting angry at the partner.

Further, jealousy is defined as a defensive reaction to a perceived threat to a valued relationship. It arises from a situation in which the partner's involvement with an activity and/or another person is contrary to the jealous person's definition of their relationship (Bevan, 2004: 195-218). It is triggered by the possibility of the partner's romantic interest in another person 
(Sharpsteen \& Kirkpatrick, 1997).

Gone Girl is a story about a couple of married men and women, Nick and Amy Dunne. The story is told from two perspectives, from Nick's and Amy's. Amy disappears after she finds out that her husband has an affair with another woman. Her brilliance as a story writer manifests in her plans and actions. She is jealous and tries to avenge her husband. She disappears and makes it as if she was brutally kidnapped. She also fakes her identity and finally kills a man, who turns out to be her ex-boyfriend when she was younger.

The paper presents the causes and effects of the main character's jealousy using a psychological approach. The approach is considered appropriate since it deals with a human being's psychological aspect, with the emotion that affects attitude and behavior. In this case, the emotion is jealousy.

Flynn's work, Gone Girl, is interesting to discuss. There have been several studies discussing the work. For example, Lofti (2017) studied the personality disorder of the main character. He found that Amy Dunne has an antisocial personality disorder. It includes failure to conform to social norms, deceitfulness, irritability and aggressiveness, reckless disregard for safety or self and others, and lack of remorse.

Similarly, Sarwowigati (2018) also talked about Amy Dunne. She revealed that the main character has a psychopath characteristic, indicated by several symptoms. Those are a grandiose sense of self-worth, pathological lying, conning/manipulative, lack of remorse, or guilt. The present study completes the previous ones since none of them discussed the cause of why the main character performs all the actions. It is about jealousy that was not mentioned in other studies. Therefore, it is necessary to discuss further about the topic.

Papalia (1985, as cited in Fauziyah, 2008) mentioned that psychology is the scientific study of behavior and mental processes. The term comes from the Greek words "psyche" (the soul) and "logos" (study). It studies the soul or the mind of a human being. Besides, Rohberger and Woods (as cited in Monica, 2008) suggested a similar point of view between literature and psychology. Both of them discuss people and human life - the human soul.

Psychology observes human behaviors and their causes, while literature depicts human behavior through fiction. A literary work benefits from psychology in presenting the characters and their moods, allowing them to see the psychological dimension of human reality. Psychology and literature meet their focus on the fantasy, emotion, and inner part of a human (Emir BC, 2016).

Further, Wellek and Warren, as cited in Emir (2016), explained the psychology of literature as the psychological study of the writing -type and individual. It can also be the study of the creative process or the psychological types and laws within literary work. They proposed that 
literature influences its readers (audience psychology). Psychology tries to understand human individuality as an active subject with a unique character. An active subject means the dynamic character within their activities and experiences.

About the relationship between psychology and literature, Wellek and Warren (1989: 90) assert that a psychological approach in a literary work has four meanings. First is a psychological approach to the author as a person. The author shows the obsession to live in work, making the will a complete application. Besides, carefulness and consciousness are natural types of work. Second is the psychological approach to the creative process of literary work. The creative process of literary works contains all stages, starting from the author's unconscious level into creating the work as the last correlation made by the writer. The third is a psychological approach to the psychological rules and norms gained from literary work. Literary work is a social institution in which the language is the medium with the traditional technique of using symbolism and social aspects. It presents the conventional and social norms. Besides, literature shows facts in the life event of a human being. Fourth is a psychological approach to the influence of literary works through the readers. It means that literary work has power upon the reader's heart and stirs their motivation. Literary works show the life event of a human being to attract the readers' interest. The writer's professionalism helps to create the curiosity of the reader.

Meanwhile, related to the human psyche is jealousy. It is a part of a human's inner aspect. Jealousy is a human instinct, which is felt when a threat arises (whether it is a thing or a person) considered to harm his existence. Jealousy makes people feel uncomfortable, unappreciated, sensitive, angry, sad, and frustrated. It could even lead to anxiety or depression disorders.

Jealousy is a fundamental aspect of human social life. From Gilgamesh's romps retold in the first millennium B.C.E to Othello's throes portrayed in the middle part of the last millennium, to modern-day soap operas and drama series, fascination with the jealousy motif has not waned among artists and audiences alike. From cultures representing geographically and socially disparate milieus, research documents the pervasiveness of jealousy among men and women from childhood to old age (Bryson, 1991; Buunk, Angleitner, Oubaid, \& Buss, 1996; Geary, Rumsey, Bow, Thomas, \& Hoard, 1995; Hupka et al., 1985; Masciuch \& Kienapple, 1993 as cited in David et al., 2006). Jealousy's ubiquity is so well accepted that even Freud (1922/1955) himself suggested that its absence, not its presence (at least within reasonable levels), is a sign of pathology.

According to Guerrero, Spitzberg, and Yoshimura in their book Sexual and Emotional Jealousy (2004: 311), jealousy is defined as a cognitive-emotional and behavioral response to a relationship threat. In sexual jealousy, the threat appears from knowing or suspecting that the 
partner has a desire to have sexual activity with another. In emotional jealousy, an individual feels threatened by the partner's emotional involvement with another. Meanwhile, romantic jealousy is a complex of thoughts, feelings, and actions threatening the self-esteem and the existence or quality of a relationship. It may come from the perception of a real potential attraction between one's partner and an imaginary rival. Meanwhile, Rorty (1980: 476) mentioned that jealousy is led by depression and withdrawal, other than anger or thoughts of revenge.

In other words, jealousy is a repulsive behavior resulting from a partner's relationships. It can be real, imagined, or considered likely to occur. Jealousy is triggered by a threat or fear of separating from or losing a romantic partner, which is attributed to the possibility of the partner's interest in another person (Sharpteen and Kirkpatrick, 1997). All definitions of jealousy imply a triangle composed of a jealous individual, a partner, and a third party as a rival. It usually involves three people or more. The definitions conclude that jealousy is a reaction to a threatened feeling. It indicates an aversive emotion and protective behavior. Jealousy is a reaction that typically involves aversive emotions and protective behaviors. Parrot (as cited in Petric, 2019) focuses on the ideas and feelings that occur in jealousy. The experience includes fear of loss, suspicion about betrayal, anger, and low self-esteem, sadness over loss, uncertainty, and loneliness. It is the fear of losing a significant other for another attractive person.

It is said that jealousy is a distinct emotional response to a specific type of anticipated or actual rejection. The rejection in a relationship can be caused by an outsider considered as a rival. However, it is necessary to note that social rejection can take several forms, such as ostracism from a group, refusal of a group, and relationship ending. Jealousy is intrinsically tied to the triadic relationship mentioned previously. To put it simply, jealous distress comes from a motivation to protect the relationship people from being taken by an outsider (Salovey, 1991, as cited in DeSteno et al., 2006).

From a functional perspective, jealousy stands as a prominent example of fundamental social emotion. Like many psychological phenomena, emotions appear because they have several adaptive purposes. Despite their functions on many different levels of the human aspect, such as neurochemical, interpersonal, and cultural, emotions are set to add to the success achieved by individuals after accomplishing particular challenges through cognition and behavior (Frijda, 2000; Keltner \& Gross, 1999; Keltner \& Haidt, 1999; Lazarus, 1991; LeDoux \& Phelps, 2000; 0“ human \& Wiens, 2003). The cognitive and physiological changes associated with fear and anxiety, for example, prepare an organism to detect and/or escape from an impending danger more efficiently (LeDoux \& Phelps, 2000; 0"hman, 2002). Nevertheless, the organism of which the existence is unique for its collective or social living should face not only challenges requiring 
a successful drive of the physical environment but also social aspects. For example are social exchange, coalition building, social bonding, and relationship maintenance (Bartlett \& DeSteno, 2006; Cosmides \& Tooby, 2000; Darwin, 1872/1998; Keltner \& Buswell, 1997; Keltner \& Haidt, 1999; Lewis, 2000). The importance of such challenges suggests the need for specific emotional responses that are intrinsically tied to sociality.

Kingham and Gordon (as cited in Dewiastuti, 2007) mentioned several causes of jealousy: cognitive factors, sexual dysfunction factors, and marital and social factors. Cognitive factors are related to an individual's tendency to build false perceptions and interpretations of events and information within the relationship. The second factor is related to the insecurity felt by an individual to satisfy the partner and thus lead him or her to feel that the partner may find another individual for that matter. The third factor is seen as usual within a marriage, especially in highly conservative cultures.

As mentioned earlier, jealousy causes a fear of loss in a person. A jealous individual will experience insecurity; he or she will lose the partner's affection because of the existence of another person between the pair. Nevertheless, there are positive and negative impacts of jealousy. In her research, Newberry (2010) mentioned that jealousy appeared as an indication of love between a man and a woman. When jealousy is expressed in order to maintain investment to protect a relationship, it will have a positive outcome. In other words, the absence of jealousy may signify a lack of feeling between the pair. In this kind of context, jealousy appears as one of the ingredients of a relationship, helping a couple nurture each other.

On the other hand, jealousy may lead an individual to have negative thinking and prejudice about the partner. They will feel that their partner is doing something with another person that can threaten the relationship. When people find this out, they will become less confident, feeling that they are not good enough. Tangney \& Fischer (as cited in DeSten, 2006) suggested that sometimes jealousy could reduce people's self-confidence. In addition, Pazak (as cited in Newberry, 2010) revealed that jealousy refers to an individual's possessiveness of the partner's life, allowing him or her to control the partner. It is due to the insecurity that exists, fearing that the partner may break the relationship.

Further, jealousy can also cause aggressive behavior aimed at the partner (DeSteno et al., 2006). The prejudice upon the partner's secret relationship with another can increase the people's possessiveness. When people feel that they possess the partner, any failure to follow their wishes can trigger abusive action.

\section{Method}

The research belongs to a library study presented qualitatively. One of Gillian Flynn's novels, Gone Girl, becomes the study's subject, while the main character's jealousy the object. Several 
steps were taken to collect the data; those are defining the topic, formulating the problem, outlining, developing a search strategy, evaluating the sources, taking notes, writing and revising the paper, as well as documenting the sources (Elmer E. Rasmuson Library, 2018). The data were analyzed using a psychological approach and presented descriptively.

\section{Discussion}

\section{The main character's personality}

Amy Dunne is the main character of Gillian Flynn's Gone Girl. The title reflects the story in that Amy disappears after she finds her husband's affair. She is angry and jealous. Amy Dunne is characterized as a famous writer. She has written a popular series entitled The Amazing Amy. It should be a book about herself, from baby to when she gets married.

Since she is young, Amy is known to be brilliant. She wins everyone's heart with her talent, especially in writing. However, her brilliance is used instead in negative ways. For example, as a popular schoolgirl, she has a close friend. To gain more attention, she acts in such a way that this one friend tries to steal her identity by becoming like her. In fact, Amy manipulates the fact. Another brilliant character is present in the main character's actions during the story, such as purchasing good using Nick's name and creates clues for the anniversary that leads the police to accuse him of murder. She has also brilliantly deceived the people during her escape. However, they finally know who she is and take all her money.

Another characteristic of the main character is cunning. A cunning person will always find a way to achieve his goals. Combined with her wittiness, Amy set a scheme of her own murder. She plots a series of events and creates clues that lead people and detectives to suspect her husband. Money and affair are used to let the public think that Nick is a bad person and Amy is innocent. She also cunningly traps Desi and finally kills him in a fake rape. She uses his admiration and affection towards her to convince her lies.

The main character's personality is reflected in her attitude and behavior in facing the problems in her marriage life. She finds her happiness when she marries him. Nevertheless, she accepts the fact that they have, such as when they have lost the jobs, follow Nick to take care of his mother, finds her husband's affair, and finally returns after some unlawful incidents. She assures herself that she is in love with her husband no matter what they have had. She convinces Nick that she is the only woman of his. Jealousy is part of the human psyche. Similar to envy, it involves the fear of the loss of someone or something we love. Jealousy shows that a person is in love with another. However, it also leads to misconduct if the person experiencing it has unusual ways of thinking. 


\section{Causes of Amy's Jealousy}

There is always a cause for any conflict among individuals or between an individual and a group, or even between an individual and the self. It is also found in every literary work because a story will be more interesting if there is an explanation of the origin of conflict. In short, every event, situation, and condition can occur due to a particular factor. Likewise, the actions carried out by Amy in the novel "Gone Girl" have a cause. The main female character, Amy Dunne, is a famous children's story. Supported by her parents, she succeeded in being a role model for almost every girl in the city. She married a journalist, Nick Dunne, and they live happily until she found her man with a girl.

From then on, Amy observed her surroundings and her husband's activity without him realizing the action. She plans an escape and prepares everything so perfectly that no one knows the truth until the end of the story. She arranges her plans so carefully that people believe that her husband is the main actor. It all starts with her jealousy.

The first cause of Amy's jealousy is the economic factor. They were both successful writers with high incomes. However, the recession occurs. They lost their job. Amy is frustrated because her parents demand a large sum of money from her success in writing her popular book, The Amazing Amy.

On top of that, they are forced to move back to Nick Dunne's hometown because his mother is diagnosed with breast cancer. In his home, Missouri, Nick is offered a job as a writing teacher in a college. Nevertheless, soon after his mother's death, the financial condition does not get any better. The relationship between Amy and Nick declined. Amy lost her husband's attention, adding to her discomfort because she does not feel at home in the city.

Economic factor significantly affects the relationship between husband and wife. When needs continue to increase but income decreases, there will be an imbalance in the family. We can refer to events that occur in the community, where economic conditions often cause murders, domestic violence, and divorce. Since Nick lost his job, Amy feels the financial burden is escalating, and Nick does nothing to overcome the problem. He enjoys the situation, and once the opportunity comes, he has an affair with a girl who is his student. It leads to the second cause of her jealousy. Amy finds her husband is cheating on a girl, whom later she knows is his student. She continues to follow Nick for days and starts to plan to avenge her jealousy.

When a person is jealous, he will feel that he has lost the partner's attention. Therefore, he will do anything to get it back. Nick has a relationship with a young girl named Andie, who is a 23-year-old student. He does not realize his wife's attitude changes, nor is he aware that 
Amy has known about the affair. Amy is angry about it because she has sacrificed her career and wealth to support the family. Nick admits it in the part of the story where the point of view used is his:

I [Nick] have a mistress. Now is the part where I have to tell you I have a mistress, and you stop liking me. If you liked me to begin with. I have a pretty, young, very young mistress, and her name is Andie. I know. It's bad. (Flynn, 2012: 161).

In her book Explaining Emotions (1980: 476), Rorty states that some jealousies are intended by depression and withdrawal, others by anger or thoughts of revenge. Jealousy is a natural thing and is experienced by everyone. Jealousy is an aversive reaction resulted from a partner's extradyadic relationship. It can be is real, imagined, or considered likely to occurs. Jealousy is triggered by the threat of separation from, or loss of, a romantic partner. It is mainly when the threat is attributed to the possibility of the partner's romantic interest in another (Sharpteen and Kirkpatrick) 1997:628). Jealousy can be influenced by many factors, such as the relationship of ownership towards someone excessively or feeling angry about being mistreated.

\section{Impacts of the main character's jealousy}

When people are jealous, they may plan to do some actions to satisfy their feeling. Jealousy is mostly about the relationship between one person to another. Anger, fear of loss, and distrust may indicate a person's jealousy. The main character of Flynn's Gone Girl is a famous writer of a popular children's book called The Amazing Amy. It actually reflects the happiness that Amy pursues. Even so, the reality is not like what other people see. She brings envy from her readers because, in "Amazing Amy," the children's story that she writes shows herself as a happy and cheerful child. It goes on until she marries Nick. The story represents her life, and it has been a best-seller.

Amy is such a brilliant writer that all her stories steal the readers' amazement. The character she writes becomes the role model for others. With such an intelligent and witty brain, the main character decides to avenge her husband. As mentioned previously, jealousy may lead an individual to do unusual actions. Pazak, as cited in Newsberry (2010), mentioned that when a person feels jealous, he or she may become over-possessive for the partner. Similarly, Amy feels that her husband should not have had an affair. She thinks that she needs to give her husband a lesson. She does several actions to realize her plans.

First, Amy observed her husband's activity day and night. Jealousy may trigger a person to keep his eye on his partner, growing distrust and fearing of losing the partner. Amy has lost her husband's attention, especially after she knows that he has an affair. Without any 
suspicion, Amy plans a scheme.

Second, she prepares all the lies and scenarios. Indeed, she takes the benefits of her neighbor's innocence. Only with a small argument, the neighbor is convinced that Nick and Amy have such a great quarrel that causes him to murder his wife. She purchases stuff and creates a diary entry to convince her lies.

Third, she disappears and leaves her home as if she was murdered. Using their anniversary rituals, Amy gave clues to her husband. Each of them refers to their marriage and the affair that he committed. She creates such a perfect scenario that every step taken by her husband to find her leads the public to blame his decision. Indeed, she makes Nick admit that he has had an affair with his student.

All the plans run as she expects. Even the police trust the clues she prepares before disappearing. The messy rooms, notes, and pieces of her clothes confirm that something terrible has happened to the woman. The fake death implies Nick's reputation. Reputation is something invisible but precious. Reputation is a valuable asset for most people. When someone has a good and respectable reputation, that person will be more appreciated and respected. Nick is a writer and a lecturer at a university. He has mediocre reputations that are enough to make him live in peace.

However, while following the rumors and news about herself during the escape, she was almost caught by people she encounters. She is threatened and robbed. Amidst the anger and despair, she recalls another strategy that she plans. Being a witty story writer has helped her in taking all the actions.

Jealousy has positive and negative impacts. Feeling jealous of the partner indicates the love people have towards the other-self. The sense of belonging triggers a person to fear that the partner may leave if another person comes into the relationship. Nevertheless, the negative impacts of jealousy are more common in society; it leads people to do things beyond their own prediction. Possessiveness may cause destruction.

When Amy Dunne has lost all her money, she does not give up her attempts to take revenge. What she has in mind is to make her husband feel what she feels. Indeed, she wants her husband to believe that Amy is the only one for him. A jealous person will find a way to satisfy his anger. Amy takes her fourth plan, scheming a rape.

Amy recalls her memory when she was much younger. People, especially women, envy her popularity. The truth is, Amy is the one who makes herself look important. People are conveyed when they see Amy's close friends try to look like her and want everything that she has. As a matter of fact, Amy cunningly set her friends or the people around her to increase her fame. One of the victims is her ex-boyfriend, Desi. 
Death is an unfortunate thing, and every human being faces death. However, death can be falsified to lead the public opinion. The very unnatural conduct becomes part of Amy's plan after finding her husband's affair. In her plans, she makes Desi believe all the facts she told. Desi was in love once, and he bluntly follows whatever Amy instructs. Before going home, Amy performs her last action, which is faking a rape and in such a way convince the police that she kills Desi to defend herself.

Jealous people tend to be more obsessive towards their partners. When they feel that the attention is decreasing, they will do anything they can to return the condition. After returning home, Amy acts as if nothing has happened before. Nick is suspicious and knows that she has created all the perfect scenarios for him. She knows that Nick realizes the fact, but she never discusses it with him. Nick is aware of Amy's wittiness. She knows that Nick tries to find the truth, but she is confident that Nick cannot do anything about it.

The jealousy that grows within the people's minds can lead them to do the unlawful deed. After finding the affair, Amy wants the public to believe that Nick is cruel and barbaric, despite his handsome face and lovely behavior. Nick has taken several press conferences showing his despair and hopelessness of Amy's disappearance. However, it does not return the people's trust toward him.

\section{Conclusion}

Jealousy exists in all humans, either positively or negatively. When people are jealous, they will do anything to relieve their minds. The main character is described as a brilliant and cunning woman because these are present in all her actions in the story. The main character is jealous of her husband. There are several causes of jealousy experienced by the main character of Flynn's Gone Girl: economic factor and unfaithfulness. Jealousy leads the main character, Amy Dunne, to committing several crimes. For example, faking her death, damaging her husband's reputation, and killing another person to return herself into her life. The novel is interesting to discuss. The use of point of view and the plot twist can still be further analyzed. Besides, further research can explore the work's usefulness in English language learning.

\section{References}

Anonymous. About Gillian Flynn. http://gillian-flynn.com/aboutgillianflynn

Bevan, J.L. (2004). "General partner and relational uncertainty as consequences of another person's jealousy expression." Western Journal of Communication. 68 (2), pp 195-218.

Demirtaz, H., \& Andac, A. D. (2006). Jealousy in close relationships: Personal relational and situational variables. Turkish Journal of Psychiatry. 17 (3): 181-91.

David, D., Valdesolo, P., \& Bartlett, M.Y. (2006). "Jealousy and the threatened self: Getting to the 
heart of the green-eyed monster." Journal of Personality and Social Psychology. 91 (4), 626-41.

Dewiastuti, R. (2007). A Study of jealousy as reflected on leontes a major character of the winter's tale a play by William Shakespeare (a psychological approach). Undergraduate Thesis. Universitas Negeri Sebelas Maret Surakarta.

Elmer E. Rasmuson Library. (2018). Library research process. Retrieved September 9, 2020, from https://library.uaf.edu/ls101-research-process

Emir, B. C. (2016). Literature and psychology in the context of the interaction of social sciences. Khazar Journal of Humanities and Social Sciences, 19(4): 49-55.

Fauziyah, N. (2008). Psychological analysis of the main character's personality in go ask Alice. A Thesis. The State Islamic University of Malang. Malang.

Frijda, N. H. (2000). The psychologists' point of view. In M. Lewis \& J. M. Haviland-Jones (Eds.), Handbook of emotions (2nd ed., pp. 59-74) New York: Guilford Press.

Flynn, G. (2013). Gone girl. UK: Weidenfeld \& Nicolson.

Guerrero, L. K., Spitzberg, B. H., \& Yoshimura, S. M. (2004). Sexual and emotional jealousy. In J. H. Harvey, A. Wenzel, \& S. Sprecher

LeDoux, J. E., \& Phelps, E. A. (2000). Emotional network in the brain. In M. Lewis \& J. M. HavilandJones (Eds.), Handbook of emotions (2nd ed., pp. 157-172). New York: Guilford Press.

Lofti, T. M. (2017). The personality disorder of the main character as reflected in gone girl by Gillian Flynn: A Psychological approach. A Thesis. Universitas Ahmad Dahlan. Yogyakarta.

Monica, H. (2008). The main character's motivation in saving viscos as seen in Paulo Coelho's the devil and mis Prym. A Thesis. Sanata Dharma University. Yogyakarta.

Oxford Learner's Dictionary (https://www.oxfordlearnersdictionaries.com/)

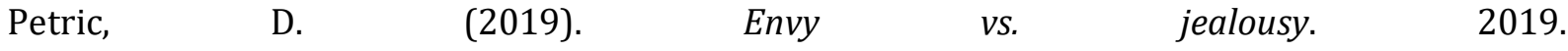
https://www.researchgate.net/publication/330523544_Envy_vs_jealousy

Rorty, O. A. (1980). Explaining emotion. Los Angeles (London): University of California Press

Sarwowigati, A. S. (2018). The portrait of a psychopath as reflected in Gillian Flynn's gone girl: A Psychological Approach. A Thesis. Universitas Ahmad Dahlan. Yogyakarta.

Sharpsteen, D.J.; Kirkpatrick, L.A. (1997). "Romantic jealousy and adult romantic attachment." Journal of Personality and Social Psychology. 72 (3), 627-640

Wellek, R., \& Warren, A. (1989). Theory of literature. New York: Harcourt Brace and World. Inc. 